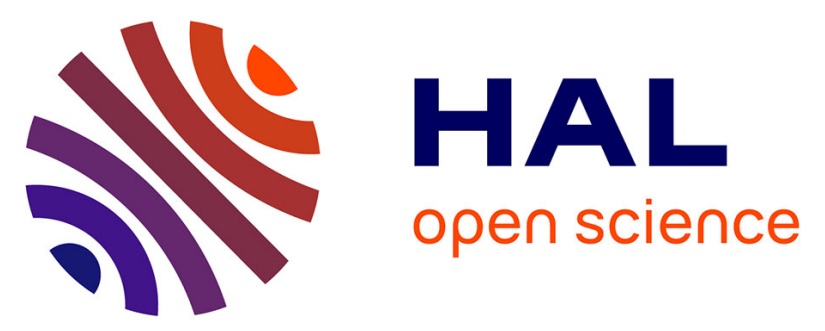

\title{
How good are rodent models of carcinogenesis in predicting efficacy in humans? A systematic review and meta-analysis of colon chemoprevention in rats, mice and men.
}

\author{
Denis E. Corpet, Fabrice H.F. Pierre
}

\section{To cite this version:}

Denis E. Corpet, Fabrice H.F. Pierre. How good are rodent models of carcinogenesis in predicting efficacy in humans? A systematic review and meta-analysis of colon chemoprevention in rats, mice and men.. European Journal of Cancer, 2005, 41 (13), pp.1911-22. 10.1016/j.ejca.2005.06.006 . hal00334699

\section{HAL Id: hal-00334699 \\ https://hal.science/hal-00334699}

Submitted on 27 Oct 2008

HAL is a multi-disciplinary open access archive for the deposit and dissemination of scientific research documents, whether they are published or not. The documents may come from teaching and research institutions in France or abroad, or from public or private research centers.
L'archive ouverte pluridisciplinaire HAL, est destinée au dépôt et à la diffusion de documents scientifiques de niveau recherche, publiés ou non, émanant des établissements d'enseignement et de recherche français ou étrangers, des laboratoires publics ou privés. 


\title{
How good are rodent models of carcinogenesis in predicting efficacy in humans? A systematic review and meta-analysis of colon chemoprevention in rats, mice and men.
}

\author{
Denis E. Corpet*, Fabrice Pierre \\ UMR1089 Xenobiotiques, INRA \& ENVT, Ecole Nationale Veterinaire Toulouse, BP-87614, 23 Capelles, 31076 Toulouse, France \\ Received by EJC 31 March 2005; received in revised form 13 June 2005; accepted 15 June 2005 \\ Available online 9 August 2005
}

\begin{abstract}
Tumours in rodent and human colon share many histological and genetic features. To know if rodent models of colon carcinogenesis are good predictors of chemopreventive efficacy in humans, we made a meta-analysis of aspirin, betacarotene, calcium, and wheat bran studies. Controlled intervention studies of adenoma recurrence in human volunteers were compared with chemoprevention studies of carcinogen-induced tumours in rats, and of polyps in Min (Apc(+/-)) mice: 6714 volunteers, 3911 rats and 458 mice were included in the meta-analyses. Difference between models was small since most global relative risks were between 0.76 and 1.00. A closer look showed that carcinogen-induced rat studies matched human trials for aspirin, calcium, carotene, and were compatible for wheat bran. Min mice results were compatible with human results for aspirin, but discordant for calcium and wheat bran (no carotene study). These few results suggest that rodent models roughly predict effect in humans, but the prediction is not accurate for all agents. Based on three cases only, the carcinogen-induced rat model seems better than the Min mouse model. However, rodent studies are useful to screen potential chemopreventive agents, and to study mechanisms of carcinogenesis and chemoprevention.
\end{abstract}

Keywords: Animal model; Diet; Chemoprevention; Colon-carcinogenesis; Min mice; Chemically-induced; Aspirin; b-carotene; Calcium; Wheat bran; Meta-analysis; Systematic review

\section{Introduction}

Some 100,000 rodents have been sacrificed on the chemoprevention altar. This number was estimated from the colon cancer chemoprevention database :

http://www.inra.fr/reseau-nacre/sci-memb/corpet/indexan.html The estimate also includes liver, mammary, oesophagus, pancreas prostate, and skin cancer studies. Were these sacrifices useful? Were the time, efforts, and money needed to raise rodents, and to try to prevent their tumours of any use? The answer may seem obvious, since rodents and humans share many biological functions, and rodents are valuable for toxicity tests. Rodent studies are needed in the chemoprevention area, because epidemiological studies do not lead to firm conclusions: confusing factors cannot be fully eliminated. Thus, the hypotheses generated by epidemiology must be tested in controlled experiments, ideally in humans (1). But this is very long and costly, and it could jeopardize volunteers' health. Thus, animal trials should precede human trials. For instance, animal studies should have been completed before beta-carotene administration to smokers $(2,3)$. It is not, however, so obvious that animal chemoprevention studies are useful (4). Major differences between rodents and humans in lifespan, body weight, intestinal morphology (e.g., caecum), gut microflora, way of eating (e.g., meals, chewing, coprophagia), and gene regulation may change the outcome of dietary interventions. Also, the profound differences in efficacy seen, even in different studies using one model, cast doubt on their relevance for clinical studies (5). The question thus needs to be scrutinized.

How good are rodent models of carcinogenesis in predicting chemopreventive efficacy in humans? From a theoretical viewpoint, how similar, or dissimilar, are rodent and human tumours? From an empirical viewpoint, are the chemopreventive effects of agents tested in rodents and humans consistent or discrepant? This review focuses on colorectal cancer prevention only, and goes through four steps: (i) Comparison of the mechanisms of colon carcinogenesis in humans and in animal models. (ii) Review of human intervention studies aimed at preventing colorectal tumours. (iii) Meta-analysis of animal intervention studies (4). The meta-analysis was restricted to aspirin, beta-carotene, calcium and wheat bran, the only agents tested in several human trials. (iv) The efficacy of chemopreventive agents in animals and in humans was then compared.

\section{Comparison of the mechanisms of colon carcinogenesis in humans and in animal models}

Let us look first at colon carcinogenesis in humans, then in rodent models. Vogelstein model relates the histological 
progression from normal tissue to cancer with the sequential accumulation of mutations $(6,7)$. Most human adenocarcinoma would evolve from aberrant crypt foci (ACF) and adenoma. This model has been progressively enriched, and several interdependent pathways are now accepted, based on the analysis of sporadic tumours and of two inherited syndromes: the familial adenomatous polyposis (FAP) and hereditary nonpolyposis colorectal cancers (HNPCC). Germline mutation of the $A p c$ gene determines the FAP syndrome. Most colorectal cancers are sporadic $(90 \%)$, but they share with FAP tumours the same early $A p c$ mutation in 50 to $80 \%$ of cases. In most sporadic colon cancers, like in FAP, a consequence of $A p c$ gene mutation is b-catenin accumulation. Indeed APC protein forms a complex with b-catenin, axin, and glycogen synthase-3 $\beta$ kinase (GSK3 $\beta$ ). Axin promotes $\beta$ catenin phosphorylation that mediates its degradation in the proteasome (8). In normal cell, this is regulated by the Wingless/Wnt signaling pathway. But Apc mutation prevents the formation of the complex, and b-catenin level rises in the cytoplasm. The stabilized $\beta$-catenin associates with transcription factor Tcf4. b-catenin-Tcf4 translocates into the nucleus, and induces constitutive activation of $c$ myc, cyclin Dl and $c$-jun (9). The disruption of the Wnt/bcatenin/Tcf pathway is thus a major event in most colon cancers. Chromosomal instability (CIN), a common feature of 8/10 colorectal cancers (10), goes with Apc mutation. Truncated APC protein may loose its ability to connect chromosomes to microtubules. Defective chromosome segregation, and CIN, would thus result from mutated $A p c$. Furthermore, in the tumours where $A p c$ is intact, the b-catenin gene is mutated, and stabilized $\beta$ catenin translocates into the nucleus and triggers $c$-myc, cyclin DI and $c$-jun. In the multiple steps process from normal cell to carcinoma, other genes are mutated or deleted. The oncogene K-ras is mutated in the early stage of colon carcinogenesis, while tumour suppressor genes (DCC and p53) are involved in later stages (11). The process is also associated with over-expression of iNOS and COX-2, with resulting increase in nitric oxide and prostaglandin E2 levels. HNPCC syndrome is not due to $A p c$ mutation but to a mutation in a mismatch repair (MMR) gene: several MMR genes are implicated as first event (Mlh1, Msh2, Msh6, Pms1, Pms2). Mutation rate is 100-1000-fold greater in MMR-deficient cells than in normal cells. This is evidenced by microsatellite instability (MSI), which participates to the hypermutable phenotype (12). Most microsatellites are found in noncoding DNA, but some mutations due to MSI modify genes involved in later stages of carcinogenesis, e.g., transforming growth factor- $\beta$ receptor II and insulin like growth factor II receptor. Besides mutations, human tumours have a general DNA hypomethylation, but the aberrant hypermethylation of promoter $\mathrm{CpG}$ islands leads to transcriptional silencing of key growth-controlling genes and contributes to cancer progression (13).

Do tumours in animal models, i.e. carcinogen-initiated rats and mutated mice, share the genetic events and the histological features of human cancers? The use of carcinogens has been necessary because laboratory rodents have extremely low spontaneous rates of colon cancer. Most published studies were done in rats injected with dimethylhydrazine (DMH) or its metabolite, azoxymethane (AOM). AOM-induced tumours in rats share many histopathologic characteristics with human tumours, and similarly go through ACF, adenoma (often polyps) and carcinoma. They, like human tumours, often bear $K$-ras mutation (30-60\%), but, unlike human tumours, they seldom have a mutated $A p c$ (8\%), and never a p53 mutation. However, like $A p c$ mutated human tumours, rat tumours accumulate b-catenin in the nucleus. This is due to Ctnnbl mutation, which produces a b-catenin resistant to degradation (14). Alternatively, a mutation in the GSK3b phosphorylation motif of the $b$-catenin gene can reduce $b$ catenin degradation (15). Heterocyclic amines, e.g., 2amino-1-methyl-6-phenylimidazo[4,5-b]pyridine (PhIP), are also used to induce tumours in rats or mice. PhIP induces Apc (15\%) and $\square$-catenin mutations (50\%) in the colon of rats (16). The direct acting nitrosamine methylnitrosourea (MNU) has been used in few studies. In contrast with DMH-, AOM- and PhIP-induced tumours, no Apc or bcatenin mutations were detected in MNU-induced tumours. Thus, Wnt/ $\square$-catenin/Tcf pathway plays a major role in human tumours and in carcinogen-induced rat tumours. Like in humans, COX-2 and iNOS are overexpressed in these tumours. However, these rodent carcinogens are not found in human diet (except PhIP), and use of large doses of a carcinogen is not comparable to the human situation. Although the carcinogen-induced tumours look similar to human tumours, we do not really know if they develop like spontaneous tumours. Perhaps the protection (or the promotion) depends on the tumour initiator.

A mutant mouse, Min, was found with multiple intestinal neoplasia in 1990 (17). It was shown to have a germline inactivation of one $A p c$ gene, similar to that in patients with FAP, and in many sporadic cancers. This promising animal model mimics the rapid development of adenomatous polyps that affect FAP patients. The Apc protein deficiency in Min mice results from a premature translational stop codon at amino acid 850. Other mice have also been genetically modified on $A p c$ with truncations in positions $580,716,1309$, or 1638 . Like in humans, different mutations lead to different phenotypes and $\mathrm{Wnt} / \mathrm{b}$ catenin/Tcf pathway plays an important role in mutant mice carcinogenesis. For instance, Min mice have ten times more polyps than Apc1638, but six times fewer than Apc716 mutant mice (18). In addition, COX-2 and iNOS play an important role in Min mice carcinogenesis, like in humans: knockout Min mice with deleted COX-2 or iNOS gene(s) develop fewer adenomas than "wild-type" Min mice (19, 20). Like in humans, methylation plays a role in Min mice carcinogenesis, since a reduction in DNA methyltransferase activity suppresses polyp formation (21). K-ras and p53 mutations are not detected in Min mice tumours, in contrast with human tumours. Besides Apc mutant mice, mice with $M s h 2$ or $M l h 1$ gene mutations were obtained, but their phenotype does not make them a clear model for HNPCC patients (22). However, Msh2-deficient mice develop small intestinal tumours and sebaceous gland tumors analogous to Msh2-mutated patients (MuirTorre syndrome). Like human HNPCC, Msh2-/- and Mlh1-/- mouse cells display high mutation frequencies and MSI (23). 
Table 1: Experimental colon tumour prevention in Man. Randomized double-blinded placebo-controlled published intervention studies are ranked by potency to prevent polyp recurrence, and grouped by agent.

\begin{tabular}{|c|c|c|c|c|c|c|c|}
\hline Agent or Diet & Reference & $\begin{array}{l}\text { Relative Risk } \\
\text { (95\% confidence } \\
\text { interval) }\end{array}$ & $\begin{array}{l}\text { No. of } \\
\text { treated } \\
\text { patients }\end{array}$ & $\begin{array}{l}\text { Length, } \\
\text { months }\end{array}$ & Daily dose & $\begin{array}{l}\text { Colon } \\
\text { endpoint }\end{array}$ & $\begin{array}{l}\text { Primary } \\
\text { endpoint }\end{array}$ \\
\hline Selenium & Clark 96 & $0.42(0.18-0.95)$ & 653 & 54 & $200 \mu \mathrm{g}$ & Cancer incid. & Skin cancer \\
\hline vitC,vitE,Bcar,Se,Zn & Hercberg 04 & $0.71(0.39-1.31)$ & 2520 & 90 & $176 \mathrm{mg}$ & Cancer incid. & All cancers \\
\hline Celecoxib & Steinbach 00 & 0.72 polyp/patient & 30FAP & 6 & $800 \mathrm{mg}$ & Polyp no. & \\
\hline Sulindac & Giardiello 02 & $0.78(0.4-1.5)$ & 21FAP & 48 & $300 \mathrm{mg}$ & Polyp no. & \\
\hline Calcium & Baron 99 & $0.85(0.74-0.98)$ & 464 & 18 & $1.2 \mathrm{~g}$ & Polyp recur. & \\
\hline Calcium & Bonithon 00 & $0.66(0.38-1.17)$ & 176 & 36 & $2 \mathrm{~g}$ & Polyp recur. & \\
\hline Calcium +vit. Mix & Hofstad 98 & $0.71(0.5-1.0)$ & 42 & 36 & $1.6 \mathrm{~g}$ & Polyp recur. & Polyp growth \\
\hline Aspirin & Baron 03 & $0.81(0.69-0.96)$ & 377 & 33 & $81 \mathrm{mg}$ & Polyp recur. & \\
\hline Aspirin & Baron 03 & $0.96(0.81-1.13)$ & 372 & 33 & $325 \mathrm{mg}$ & Polyp recur. & \\
\hline Aspirin & Benamouzig 03 & $0.61(0.37-0.99)$ & 60 & 12 & $300 \mathrm{mg}$ & Polyp recur. & \\
\hline Aspirin & Benamouzig 03 & $0.85(0.57-1.26)$ & 66 & 12 & $160 \mathrm{mg}$ & Polyp recur. & \\
\hline Aspirin & Gann 93 & $0.86(0.68-1.10)$ & 11035 & 60 & $162 \mathrm{mg}$ & Polyp incid. & Heart attack \\
\hline Aspirin & Sandler 03 & $0.65(0.46-0.91)$ & 317 & 31 & $325 \mathrm{mg}$ & Polyp recur. & \\
\hline Ursodeoxycholic acid & Alberts 05 & $0.88(0.73-1.05)$ & 661 & 32 & $750 \mathrm{mg}$ & Polyp recur. & \\
\hline Wheat bran & Alberts 00 & $0.88(0.7-1.1)$ & 719 & 35 & $+11 \mathrm{~g}$ & Polyp recur. & \\
\hline Wheat bran & MacLennan 95 & $1.2(0.8-2.0)$ & 150 & 48 & $+25 \mathrm{~g}$ & Polyp recur. & \\
\hline Wheat bran & McKeown 94 & $1.2(0.6-2.2)$ & 99 & 24 & $+15 \mathrm{~g}$ & Polyp recur. & \\
\hline Low fat & MacLennan 95 & $0.9(0.6-1.5)$ & 151 & 48 & $-7 \%$ & Polyp recur. & \\
\hline Low fat & McKeown 94 & $1.2(0.6-2.2)$ & 99 & 24 & $-9 \%$ & Polyp recur. & \\
\hline Low fat & Schatzkin 00 & $1.00(0.90-1.12)$ & 958 & 36 & $-10 \%$ & Polyp recur. & \\
\hline Beta-carotene & Greenberg 94 & $1.01(0.85-1.20)$ & 359 & 48 & $25 \mathrm{mg}$ & Polyp recur. & \\
\hline Beta-carotene & MacLennan 95 & $1.5(0.9-2.5)$ & 156 & 48 & $20 \mathrm{mg}$ & Polyp recur. & \\
\hline Beta-carotene & Hennekens 96 & $1 \mathrm{NS}$ & 11035 & 144 & $25 \mathrm{mg}$ & All cancers & Heart attack \\
\hline Beta-carotene & Malila 99 & $0.98(0.71-1.35)$ & 7761 & 78 & $20 \mathrm{mg}$ & Polyp incid. & Lung cancer \\
\hline Fruits \& vegetables & Schatzkin 00 & $1.00(0.90-1.12)$ & 958 & 36 & +2 serv & Polyp recur. & \\
\hline Vit. C + vit. E & Greenberg 94 & $1.08(0.91-1.29)$ & 380 & 48 & $1+0.4 \mathrm{~g}$ & Polyp recur. & \\
\hline Vit. $\mathrm{C}+$ vit. $\mathrm{E}$ & McKeown 88 & $0.86(0.51-1.45)$ & 70 & 24 & $0.4+0.4 \mathrm{~g}$ & Polyp recur. & \\
\hline Vit. E & Malila 99 & $1.66(1.19-2.32)$ & 7768 & 78 & $50 \mathrm{mg}$ & Polyp incid. & Lung cancer \\
\hline Psyllium & Bonithon 00 & $1.67(1.01-2.76)$ & 198 & 36 & $3.5 \mathrm{~g}$ & Polyp recur. & \\
\hline
\end{tabular}

The $(A p c(+/-))$ mice are promising models of human colorectal cancer (24). However, a major drawback is that the tumours occur predominantly in the small intestine, not the colon. In addition, ACF and adenocarcinomas are not or seldom observed in this model. However, two new mutant mice may avoid these drawbacks. Germline targeted deletion of $A p c$ exon 14 leads to severe colon polyposis: 515 polyps develop in these mice colo-rectum, vs. 0.4-4 in other $A p c$ mutants (25). Other mice, with a N-terminal truncated $\square$-catenin $\left(A 33^{\square \mathrm{N} \square \text { cat }}\right.$ ), develop few spontaneous $\mathrm{ACF}$ in the colon, like human and rat models (26).

Taken together, rodent models grow tumours that share many histological and genetic features with humans. The major differences between rodents and humans are the small bowel location of tumours in Min mice (vs. human colon), and the mutation of beta-catenin gene in AOMinjected rats (vs. human Apc mutations). These conclusions render it pertinent to examine studies of intestinal tumour chemoprevention in humans, and to compare them with results obtained in rodent models.

\section{Experimental chemoprevention of intestinal tumours in humans}

Randomized, placebo-controlled trials directed at preventing the recurrence of colonic adenomatous polyps in human volunteers are considered the gold standard for chemoprevention studies though they do have limitations. The major one is that the study end-point is not cancer incidence but adenoma recurrence. Other limitations are the short length of the intervention compared with the duration of the disease, the possible lack of compliance with the protocol, and the inclusion of subjects that differ from the general population (3). Two agents, calcium (27-29) and aspirin (30-32), consistently reduced polyp recurrence in several intervention studies (Table 1). The estimated "weighted mean RRs" for calcium and aspirin were 0.79 and 0.85 respectively (weighted by study size). A recently published meta-analysis finds an $\mathrm{RR}=0.80$ (CI: 0.68 , 0.93 ) for calcium supplement (33), which is close to the value estimated here, 0.79 . Interventions with high wheat bran and/or low fat diet, beta-carotene or vitamin $\mathrm{C}$ and $\mathrm{E}$ had no effect at all on polyp recurrence (34-39). The "weighted 
Table 2: Meta-analysis of chemoprevention studies in carcinogen-initiated rats, dealing with aspirin, beta-carotene, calcium and wheat bran protection. Relative risks (RRs) calculated with Random Model, except underlined values, calculated by Chi-square test on 2x2 tables. Data subsets shown in italics (full data and figures on http://corpet.net/min)

\begin{tabular}{|c|c|c|c|c|c|}
\hline Treatment & $2 \times 2$ Table & of Rats & $\mathrm{RR}$ & 95\% C.I. & $\mathrm{p}$ Value \\
\hline & With tumour & Total & & & \\
\hline Aspirin treated rats & 313 & 559 & 0.84 & $0.75-0.95$ & 0.006 \\
\hline No aspirin controls & 167 & 252 & 0.86 & $0.77-0.96$ & 0.007 \\
\hline Aspirin during initiation only & & & 0.68 & $0.42-1.16$ & 0.13 \\
\hline Aspirin "both" periods & & & 0.80 & $0.67-0.95$ & 0.012 \\
\hline Aspirin post-initiation only & & & 0.92 & $0.79-1.08$ & 0.32 \\
\hline Beta-carotene treated rats & 54 & 95 & $\underline{0.76}$ & $\underline{0.61-0.93}$ & $\underline{0.005}$ \\
\hline No beta-carotene controls & 82 & 109 & 0.72 & $0.47-1.08$ & 0.11 \\
\hline High calcium treated rats & 548 & 984 & $\underline{0.91}$ & $\underline{0.84-0.99}$ & $\underline{0.03}$ \\
\hline Low calcium controls & 456 & 748 & $\overline{0.92}$ & $0.85-1.00$ & $\overline{0.06}$ \\
\hline Calcium in High Fat diets & & & 0.93 & $0.86-1.02$ & 0.11 \\
\hline Calcium in Low Fat diets & & & 0.92 & $0.77-1.11$ & 0.38 \\
\hline Calcium lactate & & & 0.72 & $0.55-0.94$ & 0.02 \\
\hline Ca phosph., carbon., gluconate & & & 0.99 & $0.95-1.04$ & 0.74 \\
\hline Wheat bran treated rats & 307 & 595 & $\underline{0.83}$ & $0.75-0.91$ & $\underline{0.0002}$ \\
\hline No wheat bran controls & 355 & 569 & 0.87 & $0.77-0.97$ & 0.015 \\
\hline Wheat bran in High Fat diets & & & 0.79 & $0.66-0.93$ & 0.006 \\
\hline Wheat bran in Low Fat diets & & & 0.91 & $0.78-1.07$ & 0.26 \\
\hline
\end{tabular}

mean RRs" were estimated to be $0.96,1.00,1.00$ and 1.04 respectively. Table 1 shows the effect of other interventions: mixtures, complex dietary changes, or once only tested agents. We chose to focus this meta-analysis on agents fulfilling two criteria: (i) well-defined agent, (ii) several concordant human trials. Accordingly, aspirin, beta-carotene, calcium, and wheat bran effect in rodents were further examined.

\section{Chemoprevention in animal models of intestinal carcinogenesis.}

According to the provocative article by Pound et al. (4), systematic reviews should become routine to ensure the best use of existing animal data, and improve the estimates of effect from animal experiments. We thus made a systematic review of aspirin, beta-carotene, calcium, and wheat bran dietary chemoprevention studies in two animal models of colorectal cancer: carcinogen-initiated rats (and mice), and mice mutated on the Apc gene (Min mice mainly).

\subsection{Methods.}

The meta-analysis of carcinogen-injected rats was done as follows: we searched articles on Medline/PubMed database and in "references" sections (cut-off date, January 2005). Some papers were not included: not in English, poor protocol, missing or aberrant data (list given on http://corpet.net/min). Studies were far from homogeneity (all Q Cochran's p<0.01), which disqualified "Fixed Effects" model (40). "Random Effects" model was used to calculate common RR, 95\% confidence intervals $(95 \% \mathrm{CI})$ and $\mathrm{p}$ values (40), which are shown in Table 2. Funnel plots were drawn to detect publication bias, which were tested by rank test (40). However, the Random model calculation needed to duplicate some control data, because many studies use a single control group for several treated groups. Each control rat was thus included several times in the table, which should not be. We thus added a second approach, by pooling data. It is not recommended as a rule because it gives too little weight to studies with low baseline levels of adenomas. Raw number of tumour-bearing rats, and of tumour-free rats, in control and treated groups, were included in a table, and summed up as if all rats had been treated in a single study (each control rat was included only once). The $2 \times 2$ contingency table with all rats (shown on Table 2) was then analysed with Chi-square statistics without Yates correction, and 95\% CI were calculated and shown in Table 2. Pooling of data from all studies was chosen, including rats and mice, initiated by various carcinogens, and treated with various doses. We reasoned that when a human population is treated with a chemopreventive agent, people are exposed to various carcinogens, and have different genetic backgrounds and different diets. We thus had no a priori reason to exclude any rodent protocol.

The meta-analysis of Min mice intestinal polyp studies was done as follows: Global Effect Size and p value were first calculated with "Random Effects" model (40), and given in the "Results" section. However a second approach was also used, because "Effect Size" cannot be compared with RR. We thus chose to use ratios instead of differences. Number of adenomas per mouse in treated group was divided by corresponding value in control group and multiplied by 100 , for each study. The mean of these percentages was compared with the hypothetical $100 \%$ value (H0 hypothesis) 
in a one

Table 3 Summary of dietary prevention of colorectal tumours in rats, mice and humans: Efficacy of agents to reduce polyp recurrence in humans, tumour incidence in rats, and polyp number in mice.

\begin{tabular}{|c|c|c|c|c|c|c|c|c|}
\hline \multirow[t]{2}{*}{ Agent or Diet } & \multicolumn{2}{|c|}{$\begin{array}{l}\text { Humans, } \\
\text { mean polyp } \\
\text { recurrence }\end{array}$} & \multicolumn{3}{|c|}{$\begin{array}{l}\text { Carcinogen-initiated rats, } \\
\text { colon tumour incidence }\end{array}$} & \multicolumn{3}{|l|}{$\begin{array}{l}\text { Min mice, } \\
\text { Polyp number, } \\
\text { (small bowel) }\end{array}$} \\
\hline & $\mathbf{R R}^{\mathrm{c}}$ & $\mathbf{N}^{\mathbf{e}}$ & $\operatorname{RR}(95 \% \mathrm{CI})^{\mathrm{c}}$ & $\begin{array}{l}\text { Rats } \\
\text { /men }\end{array}$ & $\mathbf{N}^{\mathbf{e}}$ & PR $(95 \% \text { CI })^{i}$ & $\begin{array}{l}\text { Mice } \\
\text { /men }\end{array}$ & $\mathbf{N}^{\mathrm{e}}$ \\
\hline Aspirin $^{\mathbf{a}}$ & $0.85 \mathrm{~S}^{\mathrm{d}}$ & 4 & $0.86(0.77-0.96)$ & $\mathrm{OK}^{\mathrm{h}}$ & 8 & $0.94(0.73-1.15)^{\mathbf{j}}$ & $\pm \mathrm{OK}$ & 7 \\
\hline Beta-carotene & $1.00 \mathrm{NS}^{\mathrm{d}}$ & 4 & $0.72(0.47-1.08)^{\mathrm{g}}$ & OK & 4 & No study & & 0 \\
\hline Calcium & $0.79 \mathrm{~S}$ & 3 & $0.92(0.85-1.00)$ & OK & 13 & $1.09-1.21$ & $\mathrm{NO}$ & 1 \\
\hline Wheat bran & $0.96 \mathrm{NS}$ & 3 & $0.87(0.77-0.97)$ & $\pm \mathrm{OK}$ & 12 & $0.64(0.54-0.84)$ & NO & 5 \\
\hline Selenium $\mathbf{b}$ & $0.42 \mathrm{~S}$ & 1 & $0.50 \mathrm{~S}$ & $O K$ & 7 & $0.60 \mathrm{~S}$ & $O K$ & 3 \\
\hline Celecoxib & $0.72 \mathrm{~S}$ & $(1)^{\mathbf{f}}$ & $0.20 \mathrm{~S}$ & $\pm O K$ & 2 & $0.60 \mathrm{~S}$ & $O K$ & 4 \\
\hline Sulindac & $0.78 \mathrm{NS}$ & $(1)^{\mathbf{f}}$ & $0.60 \mathrm{~S}$ & $\pm O K$ & 8 & $0.50 \mathrm{~S}$ & $\pm \mathrm{OK}$ & 15 \\
\hline Low fat & $1.00 \mathrm{NS}$ & 3 & $0.80 \mathrm{NS}$ & $O K$ & 10 & $0.70 \mathrm{~S}$ & $N O$ & 1 \\
\hline Fruits \& veg. & $1.00 \mathrm{NS}$ & 1 & $1.00 \mathrm{NS}$ & $O K$ & 8 & $1.20 \mathrm{NS}$ & $O K$ & 4 \\
\hline Vit. $C+$ vit. $E$ & $1.04 N S$ & 2 & $1.00 \mathrm{NS}$ & $O K$ & 11 & & & 0 \\
\hline Psyllium & $1.67 \mathrm{~S}$ & 1 & $0.36 \mathrm{~S}$ & $\mathrm{NO}$ & 1 & & & 0 \\
\hline
\end{tabular}

\section{Notes to table 3.}

a- Top-panel data come from this meta-analysis (Table 2), full data and figures on http://corpet.net/min

b- Bottom-panel data (in italics) from ref. (18): no true meta-analysis approach.

c- RR: relative risk of polyp recurrence (humans) or of colon tumour incidence (rats).

d- S, significant. NS, not significant.

e- Number of articles included in the meta-analysis.

f- Small scale study of polyp number reduction in FAP patients.

g- Not significant by Random model analysis, but significant by chi-square analysis (see Table 2).

h- OK: rodent data match human data; $\pm \mathrm{OK}$ : no direct match but human RR within 95\%CI; NO: rodent data differ from human data.

i- PR: polyp ratio, number of intestinal polyps in treated mice divided by number in control mice.

Not significant by Student's t test, but significant by Random model analysis: Effect Size $=-0.29,95 \% \mathrm{CI}=-0.55 ;-0.03$

sample Student t test. Also, a weighted mean was calculated, taking in account the number of mice per study. Full rats and mice data and figures are shown on website http://corpet.net/min, and data are summarized here in Table 2 (rats) and Fig. 1 (Min mice).

\subsection{Results}

4.2.1. Aspirin effect in carcinogen-injected rats.

The meta-analysis of eight publications (41-48) including 811 rats showed that aspirin reduces colon tumour incidence in rats: $R R=0.84(p=0.006)$, with similar $R R$ with Random model analysis $(0.86, \mathrm{p}=0.007)$. Analysis of subsets where aspirin was given only before or after the initiation is compatible with the hypothesis that the protection is higher when aspirin treatment is given during initiation (Table 2).

\subsubsection{Aspirin effect in mutated mice.}

Seven articles including 232 mice with an $A p c$ mutation provide data on aspirin (49-55). Number of intestinal adenomas in treated mice was $94 \%$ of number in controls (Fig.1, p= 0.59). Effect Size analysed by Random Model was $-0.29(\mathrm{p}=0.03)$. This small reduction of small intestinal polyps was thus significant or not, according to model. Furthermore, aspirin treatment did not reduce the number of colonic polyps (Fig.1-B). According to Perkins et al. (55) aspirin prevents the early phase of carcinogenesis, and would be active only before birth and until weaning. Data subsets were analysed to test this hypothesis. Mean number of polyps in the two early-treated groups of mice were 74 and $80 \%$ of controls (Fig. 1, open circles), vs. $102 \%$ in mice only treated after weaning. This is compatible with the hypothesis or early protection.

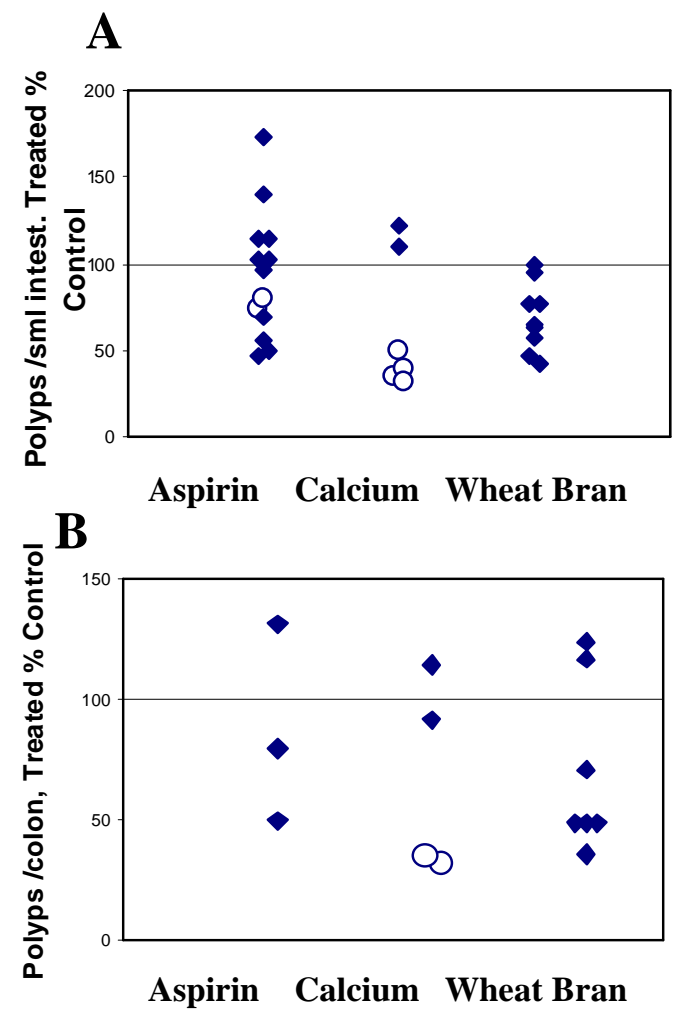

Figure 1: Effect of interventions on number of tumours in $A p c$ mutated mice, expressed as percent of control (full data on http://corpet.net/min). A: Small intestine. B: Large intestine. Open circles: pre-birth administration (aspirin), or "Western diet" (data not included into calcium metaanalysis) 
4.2.3. Beta-carotene effect in carcinogen-injected rodents. The meta-analysis of four studies (56-59) including 204 rats and mice showed that beta-carotene reduces colon tumour incidence in rodents: $R R=0.76(p=0.005)$. However, this RR was not significant using Random model analysis (0.72, $\mathrm{p}=0.11$, Table 2). No study of beta-carotene in Min mice was found.

\subsubsection{Calcium effect in carcinogen-injected rats.}

The meta-analysis of 17 publications (44, 47, 60-75) including 1732 rats showed that calcium reduces colon tumour incidence in rats: $R R=0.91(p=0.03)$, with similar RR with Random model $(0.92, \mathrm{p}=0.06)$. The hypothesis that calcium specifically reduces high-fat diet promotion was tested by analysing separately studies with high fat $(>20 \%$ fat, w/w) and low fat diets $(<6 \%)$, but both subsets yielded similar RRs and $\mathrm{p}$ values (Table 2). Also, we tested the hypothesis that some calcium salts were more protective than others. This was indeed the case: calcium lactate was protective in rats $(\mathrm{RR}=0.7, \mathrm{p}=0.02$, Table 2$)$, but phosphate, carbonate and gluconate afforded no protection $(\mathrm{RR}=1)$.

\subsubsection{Calcium effect in mutated mice.}

Small intestinal polyp yield increases by +9 and $+21 \%$ when dietary calcium doubles (ref. (76), 79 mice). Calcium did not reduce the number of colonic polyps either (Fig. 1-B). In contrast, mice fed the high-calcium AIN76 diet had fewer polyps than mice fed the low-calcium Western diet designed by Newmark (77-79). This polyp reduction to $37 \%$ of control value (weighted mean, $\mathrm{p}<0.001$ ) cannot however be attributed to calcium alone, since diets also differed for phosphate, fat, and vitamin D content (Fig 1, open circles).

\subsubsection{Wheat bran effect in carcinogen-injected rats.}

A significant protection by wheat bran is shown in two out of twelve publications (80-91). Meta-analysis, including 1164 rats, showed that wheat bran reduces colon tumour incidence in rats $(\mathrm{RR}=0.83, \mathrm{p}=0.0002)$, with similar $\mathrm{RR}$ in Random model analysis $(0.87, \mathrm{p}=0.015)$. The hypothesis that wheat bran specifically prevents fat promotion was tested by analysing separately studies with high fat and low fat diets. Wheat bran indeed protected rats given a high-fat diet $(R R=0.79, p=0.006)$, but not rats given a low-fat diet (Table 2).

\subsubsection{Wheat bran effect in mutated mice.}

The eight studies (92-96) gathering 147 Min mice showed a protective effect of wheat bran (Fig 1-A). Number of small intestinal polyps in wheat bran-fed mice was $69 \%$ of control number (weighted mean, 66\%, $\mathrm{p}=0.001$ ), and effect size was -0.74 by Random model analysis $(\mathrm{p}<0.001)$. Bran also marginally decreased colonic tumours $(\mathrm{p}=0.07$, Fig.1-B).

\section{Comparison of intestinal chemoprevention in humans and in animal models.}

Table 3 shows that aspirin, beta-carotene, calcium, and wheat bran effect in men, rats and mice led to RRs comprised between 0.72 and 1.00 (and PRs between 0.64 and 1.15): no promotion and no strong protection were observed (Fig. 2). The effects of four agents in three models were thus similar. However, Table 3 significances and 95\% CIs suggest that: (i) Aspirin protected men and rats, but
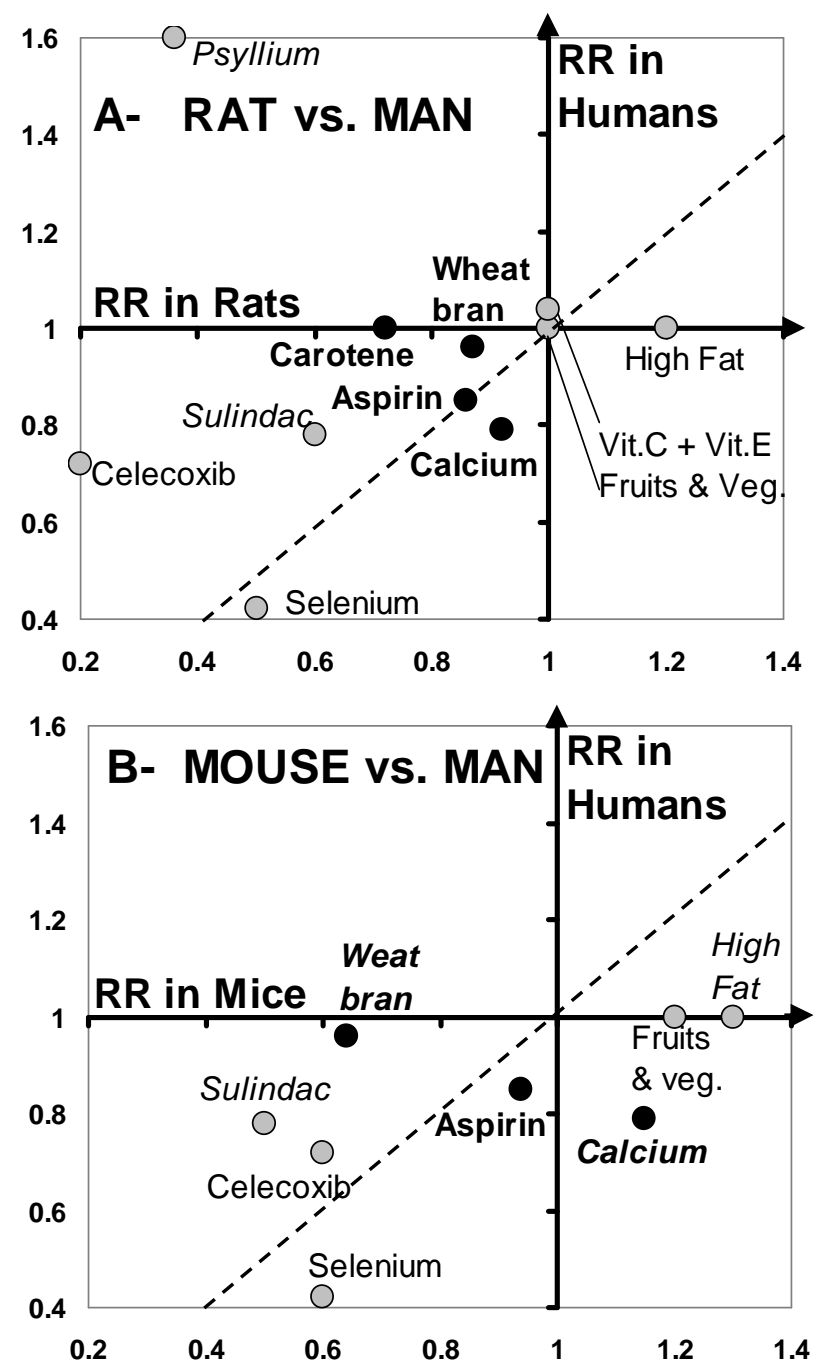

Figure 2: Chemoprevention in humans and rodents (data from Table 3). Colon polyp recurrence RR in humans vs. tumour RR in chemically-induced rats (panel RAT vs. MAN), or vs. Polyp Ratio in $A p c$ mutated mice (panel MOUSE vs. MAN). Black points: meta-analysis data. Grey points: tentative values from ref (18). Italics: RR significance discordant in humans and rodents.

not Min mice (but human RR was within mice PR 95\%CI), (ii) Beta-carotene did not protect rats or men (no published Min mice study), (iii) Calcium protected men and rats, although effect in men was stronger than in rats. In a single study, Min mice were not protected (76), and (iv) Wheat bran protected mice and rats, but not men (but human RR was within rat $95 \% \mathrm{CI}$ ). Carcinogen-induced rat studies matched human trials for aspirin, calcium, carotene, and were compatible for wheat bran. Min mice results were compatible with human results for aspirin, but discordant for calcium and wheat bran (no carotene study). However, the size of these discrepancies was small and may not be meaningful. Bottom of Table 3 reports rodent data from a previous review (18). These results should be considered with caution, because the true meta-analysis approach was not undertaken in rodents, and because the effect in humans relied on single studies (except low fat). The effect of most of the diets or agents was consistent across the various models except one striking discrepancy: psyllium afforded strong protection in one rat study, and significant promotion 
in one human study. However, the first published study of psyllium (not reported here) showed a strong promotion in DMH-initiated rats (97). The previous review concluded there was a reasonable agreement between the results of the animal studies and the more limited clinical studies (18). The present meta-analysis somewhat challenges this conclusion, because the prediction is not accurate for all agents, and carcinogen-induced rats model seems better than Min mice model.

\section{Discussion}

This meta-analysis of experimental studies suggests that the effects of aspirin, beta-carotene, calcium, and wheat bran were not strikingly different in humans, rats and mice (Fig. 2). However, the hypothesis that chemopreventive agents produce the same effect in animals and in humans has hitherto not been tested. Robust analysis would require solid data on more than four agents, and with more contrasted RRs (e.g., below 0.5 and above 1.0). Table 3 already suggests that selenium, celecoxib, and sulindac effect in rodents could match the effect in volunteers. Rodent models thus roughly predict effect in humans. A closer look at table 3 shows that carcinogen-induced rat studies matched human trials for aspirin, calcium, carotene, and were compatible for wheat bran. Min mice results were compatible with human results for aspirin, but discordant for wheat bran and calcium (single calcium article, and no carotene study). Table 3 also suggests discordances for psyllium in rats, and low fat diet in mice. Thus the rodent models do not predict accurately the outcome of intervention studies in humans for all agents, and Min mice do not appear to be superior to carcinogen-induced rats. The following four considerations may explain the apparent discrepancies between rodents and humans:

(i) Some agents may not afford the same protection in rodents and in humans (e.g., wheat bran). This means that rodent models would not be reliable predictors to detect chemopreventive agents.

(ii) Differences in study design could preclude any precise quantitative comparison between rodents and humans. Notably, genetic, diet, environment and treatment are fully controlled in rodent studies, not in human trials.

(iii) Publication bias could distort rodent results. Bias is probably much higher for rodent than for human studies. In contrast with human trials, null or negative rodent studies are less likely to be published than positive ones. This bends the mean of rodent results toward protection. For instance, several scientists have indicated to the authors that in their opinion their manuscripts were declined because the results contradicted a currently accepted dogma (e.g., calcium is protective). To illustrate this point, the funnel plot of aspirin data in rats showed a significant publication bias (plot shown on htt://corpet.net/min, $\mathrm{p}=0.0007$ ). Calcium and wheat bran data show no clear evidence for bias. However, to reduce publication bias, there should be an ethical obligation to post all unpublished results on an internet archive.

(iv) Lastly, the meta-analysis itself might be inaccurate. We may have missed important studies, or the pooling of studies with different protocols was perhaps not a good choice. Because RRs were close to 1.00 , changing the calculation method could change the significance (see notes $g$ and $j$ to
Table 3). However, these choices were made a priori, and there was no intention to bias the conclusion, which indeed contradicts the authors starting opinion.

Could the artificial use of a potent carcinogen, or of a germline mutation, be the cause of the poor predictivity of rodent models? In Newmark's model, normal mice were fed a "Western diet", which contains high fat and phosphate, and low calcium, vitamin D, fibres, folic acid and vitamin B12. Eighteen months later, spontaneous colon tumours were observed in five mice out of twelve (98). Could this model be the ultimate one to predict tumour prevention in humans, as advocated by Bruce (99)? This notion is a distinct possibility, because, like in humans, the addition of calcium (and vitamin D) to the diet reduced tumour incidence in mice (98).

Animal studies may "predict" what happens in humans. Here are two examples from our laboratory. The first example is the serendipitous discovery that polyethylene glycol (PEG) is a potent chemopreventive agent in rats (100). Four years later, a population study showed that humans taking PEG-based laxatives have only half the risk of developing colorectal adenoma compared to non-users (101). Another example is beef meat promotion of carcinogenesis in rats. According to epidemiological studies (102) consumption of beef has been suggested to increase colon cancer risk in humans. Tumour promotion by beef may be mediated by myoglobin haem iron, and is fully inhibited by a high calcium diet (103). These data prompted the authors to ask epidemiologists to re-evaluate cohort results. Such evaluation showed that high calcium intake was associated with a stronger protection in those eating high levels of red meat than in those eating less than $25 \mathrm{~g}$ red meat/day (A. Flood, unpublished observation).

Well known agents such as aspirin might perhaps not have been the best ones to be subjected to this analysis, since they seem to afford only modest protection in rats and in volunteers. One may surmise that the most potent agents discovered in animal studies might afford consistent protection when tested in volunteers. Rodent models suggest that PEG, hesperidin, Bowman-Birk protease inhibitor, sphingomyelin, physical exercise, EGF-receptor-kinase inhibitor, (+)-catechin, resveratrol, fish oil, curcumin, caffeic acid phenetyl-ester and S-methyl-methanethiosulfonate might well be efficacious preventive agents that have not yet been tested in humans $(1,18)$. However, the safety of giving a daily pill to thousand of healthy people for many years needs to be carefully evaluated prior to a trial (99), in order to avoid the negative results associated with beta-carotene and specific COX2 inhibitors (104).

In conclusion, how useful are the animal models? Do we have to agree with the letter sent by R. Greek and J. Greek to the Brit. Med. J. on 5 February, 2001? (Full text on http://bmj.bmjjournals.com/cgi/eletters/322/7281/248\#124 07) "Animals can only be proven to be "models" empirically. That is to say, we must know what happens in humans first, then study animals to see if a particular animal replicates the human condition... But this is a catch-22. We can only know which animal mimics humans after we know what happens in humans. But after we know 
how humans respond there is no need to use animals. This gives us no new knowledge, is obviously not predictive, and thus obviates the need for animals."

Although one cannot disagree completely with the underlying sentiment expressed in this letter and has to admit that the empirical approach is necessary, rodent studies remain undoubtedly useful for the following reasons:

(i) To screen for potential chemopreventive agents, and to eliminate agents that have no effect or promote tumour growth. In Table 3, all the agents which decrease polyp recurrence in volunteers also decrease tumour incidence in rats. Agents with no effect in rats produced no effect in humans. However in this demonstration tumour promoters have been omitted: no agent which promotes tumours in rodents has ever been tested in humans. It may therefore be prudent to use rodent models as screening tools: agents which turn out to be inefficacious or tumour-promoting in rodents should not be tested in humans. An appropriate role for animals in cancer chemoprevention is thus the "initial screen". Such screens may well discover as yet unknown potent chemopreventive agents like PEG $(1,100)$.

(ii) To allow the study of mechanisms. Invasive procedures and use of toxic compounds pose less ethical problems in rodents than in humans. Less time and money are required to test a hypothesis in rodents than in humans. Mice with modified or knocked out genes can be constructed to directly test some hypotheses. However one has to bear in mind that the relevance for humans of mechanisms found in rodents is doubtful if not validated in humans. For instance, attractive mechanisms explain how wheat bran prevents carcinogenesis in rats (105), but human trials show that wheat bran does not prevent colorectal adenoma.

(iii) To help identify new biomarkers and novel target genes. These can subsequently be detected in humans. For instance, $\mathrm{ACF}$ were first identified in the rat colon exposed to carcinogens (106), and they have subsequently been identified in the human colon. The numbers of ACFs increase with increasing risk of colon cancer, and they represent an attractive target for intervention (107). Also, novel gene targets were identified in human tumours on the basis of evidence collected from transcriptional profiles in Min mice (108).

Finally, this meta-analysis suggests that rodent models roughly agree with human data, but do not predict accurately the efficacy of all chemopreventive agents in humans. Human beings will however not be able to find new ways to prevent cancer without the help of animal models.

\section{Conflict of interest statement}

None declared.

\section{Acknowledgments:}

We thank W.Robert Bruce, Agnès Robin, Meige and Armelle Corpet for helpful discussions, Andy Gescher for substantial edition, the statistical reviewer for excellent advices, and many colleagues who sent their ancient papers fast to supply data for the meta-analysis.

\section{References}

1. Hawk ET, Levin B. Colorectal cancer prevention. J Clin Oncol 2005;23(2):378-91.

2. ObermuellerJevic UC, Espiritu I, Corbacho AM, Cross CE, Witschi H. Lung tumor development in mice exposed to tobacco smoke and fed beta-carotene diets. Toxicological Sciences 2002;69(1):23-29.

3. Forman MR, Hursting SD, Umar A, Barrett JC. Nutrition and cancer prevention: a multidisciplinary perspective on human trials. Annu Rev Nutr 2004;24:223-54.

4. Pound P, Ebrahim S, Sandercock P, Bracken MB, Roberts I. Where is the evidence that animal research benefits humans? British Medical Journal 2004;328(7438):514-517.

5. Gescher AJ, Steward WP. Relationship between mechanisms, bioavailibility, and preclinical chemopreventive efficacy of resveratrol: a conundrum. Cancer Epidemiol Biomarkers Prev 2003;12(10):953-7.

6. Kinzler KW, Vogelstein B. Lessons from hereditary colorectal cancer. Cell 1996;87(2):159-170.

7. Vogelstein B, Lane D, Levine AJ. Surfing the p53 network. Nature 2000;408:307-310.

8. Xing Y, Clements WK, Kimelman D, Xu W. Crystal structure of a beta-catenin/axin complex suggests a mechanism for the beta-catenin destruction complex. Genes Development 2003; 17(22):2753-2764.

9. Clevers H. Wnt breakers in colon cancer. Cancer Cell 2004;5(1):5-6.

10. Fodde R, Kuipers J, Rosenberg C, Smits R, Kielman M, Gaspar C, et al. Mutations in the APC tumour suppressor gene cause chromosomal instability. Nature Cell Biology 2001;3(4):433-438. 11. Narayan S, Roy D. Role of APC and DNA mismatch repair genes in the development of colorectal cancers. Molecular Cancer 2003;2(41):1-15.

12. Chung D, Rustgi A. The hereditary nonpolyposis colorectal cancer syndrome: genetics and clinical implications. Ann Intern Med 2003;138(7):560-570.

13. Trinh BN, Long TI, Nickel A, Shibata D, Laird PW. DNA methyltransferase deficiency modifies cancer susceptibility in mice lacking DNA mismatch repair. Molecular and Cellular Biology 2002;22(9):2906-2917.

14. Femia AP, Bendinelli B, Giannini A, Salvadori M, Pinzani P, Dolara $\mathrm{P}$, et al. Mucin-depleted foci have beta-catenin gene mutations,

altered expression of its protein, and are dose- and time-dependent in the colon of 1,2-dimethylhydrazine-treated rats. International Journal of Cancer 2005; in the press.

15. Takahashi M, Wakabayashi K. Gene mutations and altered gene expression in azoxymethane-induced colon carcinogenesis in rodents. Cancer Science 2004;95(6):475-480.

16. Tsukamoto T, Tanaka H, Fukami H, Inoue M, Takahashi M, Wakabayashi K, et al. More frequent beta-catenin gene mutations in adenomas than in aberrant crypt foci or adenocarcinomas in the large intestines of 2-amino-1-methyl-6-phenylimidazo[4,5-b]pyridine (phIP)treated rats. Japanese Journal of Cancer Research 2000;91(8):792-796. 17. Moser AR, Pitot HC, Dove WF. A dominant mutation that predisposes to multiple intestinal neoplasia in the mouse. Science 1990;247:322-324.

18. Corpet DE, Pierre F. Point: from animal models to prevention of colon cancer. systematic review of chemoprevention in min mice and choice of the model system. Cancer Epidemiology Biomarkers \& Prevention 2003;12(5):391-400.

19. Ahn B, Ohshima H. Suppression of intestinal polyposis in Apc (Min/+) mice by inhibiting nitric oxide production. Cancer Research 2001;61(23):8357-8360.

20. Oshima M, Dinchuk JE, Kargman SL, Oshima H, Hancock

B, Kwong E, et al. Suppression of intestinal polyposis in apc(delta 716) knockout mice by inhibition of cyclooxygenase 2 (COX-2). Cell 1996;87(5):803-809.

21. Laird PW, Jackson-Grusby L, Fazeli A, Dickinson SL, Jung

WE, Li E, et al. Suppression of intestinal neoplasi by DNA hypomethylation. Cell 1995;81(2):197-205.

22. DeWind N, Dekker M, VanRossum A, VanderValk M, Riele HT. Mouse models for hereditary nonpolyposis colorectal cancer. Cancer Research 1998;58(2):248-255.

23. Wei K, Kucherlapati R, Edelmann W. Mouse models for human DNA mismatch-repair gene defects. Trends in Molecular Medicine 2002;8(7):346-353.

24. Green JE, Hudson T. The promise of genetically engineered mice for cancer prevention studies. Nat Rev Cancer 2005;5(3):184-98. 
25. Colnot S, Niwa-Kawakita M, Hamard G, Godard C, Le Plenier S, Houbron C, et al. Colorectal cancers in a new mouse model of familial adenomatous polyposis: influence of genetic and environmental modifiers. Lab Invest 2004;84(12):1619-30.

26. Orner GA, Dashwood WM, Blum CA, Diaz GD, Li QJ, Alfageeh $\mathrm{M}$, et al. Response of $A p c(\mathrm{~min})$ and $A 33$ (delta $\mathrm{N}$ beta-cat) mutant mice to treatment with tea, sulindac, and 2-amino-1-methyl-6phenylimidazo[4,5- $b$ ]pyridine (phIP). Mutation Research - Fundamental and Molecular Mechanisms of Mutagenesis 2002;506(Sp. Iss.):121-127. 27. Baron JA, Beach M, Mandel JS, Vanstolk RU, Haile RW, Sandler RS, et al. Calcium supplements for the prevention of colorectal adenomas. New England Journal of Medicine 1999;340(2):101-107. 28. BonithonKopp C, Kronborg O, Giacosa A, Rath U, Faivre J. Calcium and fibre supplementation in prevention of colorectal adenoma recurrence: a randomised intervention trial. Lancet 2000;356(9238):1300-1306.

29. Hofstad B, Almendingen K, Vatn M, Andersen SN, Owen RW, Larsen S, et al. Growth and recurrence of colorectal polyps: a double-blind 3-year intervention with calcium and antioxidants. Digestion 1998;59(2):148-156.

30. Baron JA, Cole BF, Sandler RS, Haile RW, Ahnen D, Bresalier R, et al. A randomized trial of aspirin to prevent colorectal adenomas. New England Journal of Medicine 2003;348(10):891-899. 31. Sandler RS, Halabi S, Baron JA, Budinger S, Paskett E, Keresztes R, et al. A randomized trial of aspirin to prevent colorectal adenomas in patients with previous colorectal cancer. New England Journal of Medicine 2003;348(10):883-890.

32. Benamouzig R, Deyra J, Martin A, Girard B, Jullian E, Piednoir B, et al. Daily soluble aspirin and prevention of colorectal adenoma recurrence: one-year results of the APACC trial. Gastroenterology 2003;125(2):328-336.

33. Shaukat A, Scouras N, Schunemann HJ. Role of supplemental calcium in the recurrence of colorectal adenomas: a metaanalysis of randomized controlled trials. Am J Gastroenterol 2005;100(2):390-4.

34. Alberts DS, Martinez ME, Roe DJ, Guillenrodriguez JM, Marshall JR, Vanleeuwen JB, et al. Lack of effect of a high-fiber cerea supplement on the recurrence of colorectal adenomas. New England Journal of Medicine 2000;342(16):1156-1162.

35. MacLennan R, Macrae F, Bain C, Battistutta D, Chapuis P Gratten $\mathrm{H}$, et al. Randomized trial of intake of fat, fiber, and beta carotene to prevent colorectal adenomas. Journal of the National Cancer Institute 1995;87(23):1760-1766.

36. McKeown-Eyssen G, Holloway C, Jazmaji V, Bright-See E, Dion $\mathrm{P}$, Bruce WR. A randomized trial of vitamins $\mathrm{C}$ and $\mathrm{E}$ in the prevention of recurrence of colorectal polyps. Cancer Res 1988;48:47014705 .

37. McKeown-Eyssen GE, Bright-See E, Bruce WR, Jazmaji V, Toronto-Polyp-Prevention-Group. A randomized trial of a low fat high fibre diet in the recurrence of colorectal polyps. Journal of Clinical Epidemiology 1994;47(5):525-536.

38. Schatzkin A, Lanza E, Corle D, Lance P, Iber F, Caan B, et al. Lack of effect of a low-fat, high-fiber diet on the recurrence of colorectal adenomas. New England Journal of Medicine 2000;342(16):1149-1155.

39. Greenberg ER, Baron JA, Tosteson TD, Freeman DH, Beck $\mathrm{GJ}$, Bond $\mathrm{JH}$, et al. Clinical trial of antioxidant vitamins to prevent colorectal adenoma. New England Journal of Medicine 1994;331(3):141-147.

40. Cucherat M, Boissel JP, Leizorovicz A. EasyMA: a program for the meta-analysis of clinical trials. Computer Methods and Programs in Biomedecine 1997;53:187-190.

41. Craven PA, Derubertis FR. Effects of Aspirin on 1,2Dimethylhydrazine-Induced Colonic Carcinogenesis. Carcinogenesis 1992;13(4):541-546.

42. Reddy BS, Rao CV, Rivenson A, Kelloff G. Inhibitory effect of aspirin on azoxymethane-induced colon carcinogenesis in $\mathrm{f} 344$ rats. Carcinogenesis 1993;14(8):1493-1497.

43. Davis AE, Patterson F. Aspirin reduces the incidence of colonic carcinoma in the dimethylhydrazine rat animal model. Australian and New Zealand Journal of Medicine 1994;24(3):301-303. 44. Pence BC, Dunn DM, Zhao C, Landers M, Wargovich MJ. Chemopreventive effects of calcium but not aspirin supplementation in cholic acid-promoted colon carcinogenesis: correlation with intermediate endpoints. Carcinogenesis 1995;16(4):757-765.

45. Li H, Schut HAJ, Conran P, Kramer PM, Lubet RA, Steele VE, et al. Prevention by aspirin and its combination with alphadifluoromethylornithine of azoxymethane-induced tumors, aberrant crypt foci and prostaglandin e-2 levels in rat colon. Carcinogenesis 1999;20(3):425-430.

46. Barnes CJ, Lee M. Determination of an optimal dosing regimen for aspirin chemoprevention of 1,2-dimethylhydrazine-induced colon tumours in rats. Br J Cancer 1999;79(11-12):1646-50.

47. Molck AM, Poulsen M, Meyer O. The combination of 1alpha,25(OH2)-vitamin D3, calcium and acetylsalicylic acid affects azoxymethane-induced aberrant crypt foci and colorectal tumours in rats. Cancer Lett 2002;186(1):19-28.

48. Miliaras S, Miliaras D, Vrettou E, Zavitsanakis A, Kiskinis D. The effect of aspirin and high fibre diet on colorectal carcinoma: a comparative experimental study. Tech Coloproctol 2004;8 Suppl 1:s5961.

49. Mahmoud NN, Dannenberg AJ, Mestre J, Bilinski RT, Churchill MR, Martucci C, et al. Aspirin prevents tumors in a murine model of familial adenomatous polyposis. Surgery 1998;124(2):225-31. 50. Barnes CJ, Lee M. Chemoprevention of spontaneous intestinal adenomas in the adenomatous polyposis coli min mouse model with aspirin. Gastroenterology 1998;114(5):873-877.

51. Williamson SLH, Kartheuser A, Coaker J, Kooshkghazi MD, Fodde R, Burn J, et al. Intestinal tumorigenesis in the apc1638n mouse treated with aspirin and resistant starch for up to 5 months.

Carcinogenesis 1999;20(5):805-810.

52. Chiu CH, McEntee MF, Whelan J. Discordant effect of aspirin and indomethacin on intestinal tumor burden in Apc(Min/+)mice. Prostaglandins Leukot Essent Fatty Acids 2000;62(5):269-75.

53. Sansom OJ, Stark LA, Dunlop MG, Clarke AR. Suppression of intestinal and mammary neoplasia by lifetime administration of aspirin in $\mathrm{Apc}(\mathrm{min} /+)$ and $\mathrm{Apc}(\mathrm{min} /+), \mathrm{Msh} 2(-/-)$ mice. Cancer Research 2001;61(19):7060-7064.

54. Reuter BK, Zhang XJ, Miller MJ. Therapeutic utility of aspirin in the ApcMin/+ murine model of colon carcinogenesis. BMC Cancer 2002;2(1):19.

55. Perkins S, Clarke AR, Steward W, Gescher A. Age-related difference in susceptibility of Apc(Min/+) mice towards the chemopreventive efficacy of dietary aspirin and curcumin. Br J Cancer 2003;88(9):1480-3.

56. Colacchio TA, Memoli VA. Chemoprevention of colorectal neoplasms. Ascorbic acid and beta-carotene. Arch Surg 1986;121(12):1421-4.

57. Temple NJ, Basu TK. Protective effect of beta-carotene against colon tumors in mice. J Natl Cancer Inst 1987;78(6):1211-4. 58. Imaida K, Hirose M, Yamaguchi S, Takahashi S, Ito N. Effects of naturally occuring antioxydants on combined DMH and MNU intitated carcinogenesis in F344 male rats. Cancer let 1990;55: 53-59. 59. Yamamoto I, Maruyama H, Moriguchi M. Effect of betacarotene, sodium ascorbate and cellulose on 1,2-dimethylhydrazineinduced intestinal carcinogenesis in rats. Cancer Letters 1994;86(1):5-9. 60. Bull A, Bird RP, Bruce WR, Nigro N, Medline A. Effect of calcium on azoxymethane induced intestinal tumors in rats.

Gastroenterology 1987;92((5, 2)):\#1332.

61. Nelson RL, Tanure JC, Andrianopoulos G. The effect of dietary milk and calcium on experimental colorectal carcinogenesis. Dis Colon Rectum 1987;30(12):947-9.

62. Pence BC, Buddingh F. Inhibition of dietary fat-promoted colon carcinogenesis in rats by supplemental calcium or vitamin D3. Carcinogenesis 1988;9(1):187-90.

63. McSherry CK, Cohen BI, ..., Scholes J. Effect of calcium and bile acid feeding on colon tumors in the rat. Cancer Research 1989;49:6039-6043.

64. Wargovich MJ, Allnutt D, Palmer C, Anaya P, Stephens LC. Inhibition of the promotional phase of azoxymethane induced colon carcinogenesis in the F344 rat by calcium lactate : effect of simulationg 2 human nutrient density levels. Cancer Letters 1990;53:17-25. 65. Sitrin MD, Halline AG, Abrahams C, Brasitus TA. Dietary Calcium and Vitamin-D Modulate 1,2-Dimethylhydrazine-Induced Colonic Carcinogenesis in the Rat. Cancer Research 1991;51(20):56085613 .

66. Karkare MR, Clark TD, Glauert HP. Effect of Dietary Calcium on Colon Carcinogenesis Induced by a Single Injection of 1,2Dimethylhydrazine in Rats. Journal of Nutrition 1991;121(4):568-577. 67. Barsoum GH, Thompson H, Neoptolemos JP, Keighley MRB. Dietary calcium does not reduce experimental colorectal carcinogenesis after small bowel resection despite reducing cellular proliferation. Gut 1992;33(11):1515-1520. 68. Beaty MM, Lee EY, Glauert HP. Influence of dietary calcium and vitamin-d on colon epithelial cell proliferation and 1,2- 
dimethylhydrazine-induced colon carcinogenesis in rats fed high fat diets. J Nutr 1993;123(1):144-152.

69. Pence BC, Dunn DM, Zhao C, Patel V, Hunter S, Landers M. Protective effects of calcium from nonfat dried milk against colon carcinogenesis in rats. Nutrition and Cancer 1996;25(1):35-45.

70. Belbraouet S, Felden F, Pelletier X, Gastin I, Lambert D, Floquet J, et al. Dietary calcium salts as protective agents and laminin P1 as a biochemical marker in chemically induced colon carcinogenesis in rats. Cancer Detect Prev 1996;20(4):294-9.

71. Quilliot D, Belbraouet S, Pelletier X, Gueant JL, Floquet J, Debry G. Influence of a high-calcium carbonate diet on the incidence of experimental colon cancer in rats. Nutrition and Cancer 1999;34(2):213219.

72. VinasSalas J, BiendichoPalau P, PinolFelis C,

MiguelsanzGarcia S, PerezHolanda S. Calcium inhibits colon carcinogenesis in an experimental model in the rat. European Journal of Cancer 1998;34(12):1941-1945.

73. Adell-Carceller R, Segarra-Soria M, Gibert-Jerez J, Salvador Sanchis JL, Lazaro-Santander R, Escrig-Sos J, et al. Inhibitory effect of calcium on carcinogenesis at the site of colonic anastomosis: an experimental study. Dis Colon Rectum 1997;40(11):1376-81.

74. Behling AR, Kaup SM, Choquette LL, Greger JL. Lipid absorption and intestinal tumour incidence in rats fed on varying levels of calcium and butterfat. Br J Nutr 1990;64(2):505-13.

75. Ranhotra GS, Gelroth JA, Glaser BK, Schoening P, Brown SE. Cellulose and calcium lower the incidence of chemically-induced colon tumors in rats. Plant Foods Hum Nutr 1999;54(4):295-303. 76. Huerta S, Irwin RW, Heber D, Go VLW, Moatamed F, Huerta $S$, et al. Intestinal polyp formation in the apc(min) mouse effects of levels of dietary calcium and altered vitamin $\mathrm{d}$ homeostasis. Digestive Diseases and Sciences 2003;48(5):870-876.

77. Yang K, Edelmann W, Fan KH, Lau K, Leung D, Newmark $\mathrm{H}$, et al. Dietary modulation of carcinoma development in a mouse model for human familial adenomatous polyposis. Cancer Research 1998;58(24):5713-5717.

78. Yang WC, Bancroft L, Nicholas C, Lozonschi I, Augenlicht LH. Targeted inactivation of p27(kip1) is sufficient for large and small intestinal tumorigenesis in the mouse, which can be augmented by a western-style high-risk diet. Cancer Research 2003;63(16):4990-4996. 79. Yang WC, Mathew J, Velcich A, Edelmann W, Kucherlapati $\mathrm{R}$, Lipkin M, et al. Targeted inactivation of the p21(WAF1/cip1) gene enhances apc-initiated tumor formation and the tumor-promoting activity of a western-style high-risk diet by altering cell maturation in the intestinal mucosa. Cancer Research 2001;61(2):565-569.

80. Barbolt TA, Abraham R. Dose-response, sex difference, and the effect of bran in dimethylhydrazine-induced intestinal tumorigenesis in rats. Toxicol Appl Pharmacol 1980;55(3):417-22.

81. Barbolt TA, Abraham R. The effect of bran on dimethylhydrazine-induced colon carcinogenesis in the rat. Proc Soc Exp Biol Med 1978;157(4):656-9.

82. Watanabe K, Reddy BS, Weisburger JH, Kritchevsky D. Effect of dietary alfalfa, pectin, and wheat bran on azoxymethane-or methylnitrosourea-induced colon carcinogenesis in F344 rats. J Natl Cancer Inst 1979;63(1):141-5.

83. Reddy BS, Mori H, Nicolais M. Effect of dietary wheat bran and dehydrated citrus fiber on azoxymethane-induced intestinal carcinogenesis in Fischer 344 rats. J Natl Cancer Inst 1981;66(3):553-7. 84. Jacobs LR. Enhancement of rat colon carcinogenesis by wheat bran consumption during the stage of 1,2-dimethylhydrazine administration. Cancer Res 1983;43(9):4057-61.

85. Pence BC, Budding HF, Yang SP. Multiple dietary factors in the enhancement of dimethylhydrazine carcinogenesis: Main effect of indole-3-carbinol. J. Nat. Cancer Inst. 1986;77:269-276

86. Sinkeldam EJ, Kuper CF, Bosland MC, Hollanders VMH, Vedder DM. Interactive effects of dietary wheat bran and lard on Nmethyl-N'-nitro-N-nitrosoguanidine induced colon carcinogenesis in rats. Cancer Research 1990;50:1092-1096.

87. Kritchevsky D, Klurfeld DM. Interaction of fiber and energy restriction in experimental colon carcinogenesis. Cancer Letters 1997;114(1-2):51-52.

88. Takahashi T, Satou M, Watanabe N, Sakaitani Y, Takagi A

Uchida $\mathrm{K}$, et al. Inhibitory effect of microfibril wheat bran on

azoxymethane-induced colon carcinogenesis in CF1 mice. Cancer

Letters 1999;141(1-2):139-146.

89. McIntosh GH, Royle PJ, Pointing G. Wheat aleurone flour increases cecal beta-glucuronidase activity and butyrate concentration and reduces colon adenoma burden in azoxymethane-treated rats.

Journal of Nutrition 2001;131(1):127-131.
90. Wijnands MVW, van Erk MJ, Doornbos RP, Krul CAM, Woutersen RA. Do aberrant crypt foci have predictive value for the occurrence of colorectal tumours? Potential of gene expression profiling in tumours. Food and Chemical Toxicology 2004;42(10):1629-1639. 91. Reddy BS, Mori H. Effect of dietary wheat bran and dehydrated citrus fiber on 3,2'-dimethyl-4-aminobiphenyl-induced intestinal carcinogenesis in F344 rats. Carcinogenesis 1981;2(1):21-5. 92. Mutanen M, Pajari AM, Oikarinen SI. Beef induces and rye bran prevents the formation of intestinal polyps in apc(min) mice: relation to beta-catenin and PKC isozymes. Carcinogenesis 2000;21(6):1167-1173

93. Pierre F, Perrin P, Champ M, Bornet F, Meflah K, Menanteau J. Short-chain fructo-oligosaccharides reduce the occurrence of colon tumors and develop gut-associated lymphoid tissue in min mice. Cancer Research 1997;57(2):225-228.

94. Hioki K, Shivapurkar N, Oshima H, Alabaster O, Oshima M, Taketo MM. Suppression of intestinal polyp development by low-fat and high-fiber diet in Apc (delta 716) knockout mice. Carcinogenesis 1997;18(10):1863-1865.

95. Yu Z, Xu M, Santanarios G, Shen R, Izquierdopulido M, Williams DE, et al. A comparison of whole wheat, refined wheat and wheat bran as inhibitors of heterocyclic amines in the salmonella mutagenicity assay and in the rat colonic aberrant crypt focus assay. Food and Chemical Toxicology 2001;39(7):655-665.

96. Drankhan K, Carter J, Madl R, Klopfenstein C, Padula F, Lu $\mathrm{Y}$, et al. Antitumor activity of wheats with high orthophenolic content. Nutr Cancer 2003;47(2):188-94.

97. Toth B. Effect of Metamucil on tumour formation by 1,2dimethylhydrazine dihydrochloride in mice. Food Chem Toxicol 1984;22(7):573-8.

98. Newmark HL, Yang K, Lipkin M, Kopelovich L, Liu Y, Shinozaki H. A Western-style diet induces benign and malignant neoplasms in the colon of normal C57B1/6 mice. Carcinogenesis 2001;22(11):1871-1875.

99. Bruce WR. Counterpoint: From animal models to prevention of colon cancer. Criteria for proceeding from preclinical studies and choice of models for prevention studies. Cancer Epidemiol Biomarkers Prev 2003;12(5):401-4.

100. Corpet DE, Parnaud G. Polyethylene-glycol, a potent suppressor of azoxymethane-induced colonic aberrant crypt foci in rats. Carcinogenesis 1999;20(5):915-918.

101. Dorval ED, Viguier J, Bertrand P, Barbieux JP, Brondin B, Jankowski JM, et al. Prevention of colorectal adenomas by polyethylene glycol (PEG): a population-based study of 1165 colonoscopies in France. Proc. AACR 2003;44(2nd ed.):174 \#979.

102. Pierre F, Freeman A, Tache S, Van der Meer R, Corpet DE. Beef meat and blood sausage promote the formation of azoxymethaneinduced mucin-depleted foci and aberrant crypt foci in rat colons. Journal of Nutrition 2004;134(10):2711-2716.

103. Pierre F, Tache S, Petit CR, Van der Meer R, Corpet DE. Meat and cancer: haemoglobin and haemin in a low-calcium diet promote colorectal carcinogenesis at the aberrant crypt stage in rats. Carcinogenesis 2003;24(10):1683-90.

104. Gill S, Sinicrope FA. Colorectal cancer prevention: is an ounce of prevention worth a pound of cure? Semin Oncol 2005;32(1):24-34

105. Harris PJ, Ferguson LR. Dietary fibre - its composition and role in protection against colorectal cancer. Mutation Research 1993;290(1):97-110.

106. Bird RP. Observation and quantification of aberrant crypts in murine colon treated with a colon carcinogen: preliminary findings. Cancer Lett 1987;37:147-151.

107. Takayama T, Katsuki S, Takahashi Y, Ohi M, Nojiri S, Sakamaki S, et al. Aberrant crypt foci of the colon as precursors of adenoma and cancer. New England Journal of Medicine 1998;339(18):1277-1284

108. Reichling T, Goss KH, Carson DJ, Holdcraft RW, Ley-Ebert C, Witte D, et al. Transcriptional profiles of intestinal tumors in Apc(Min) mice are unique from those of embryonic intestine and identify novel gene targets dysregulated in human colorectal tumors. Cancer Res 2005;65(1):166-76. 